C2019, Elsevier. This manuscript version is made available under the CC-BY-NC-ND 4.0 license http:// creativecommons.org/licenses/by-nc-nd/4.0/

Draft version: forthcoming in Geoforum

\title{
Sustainability transitions and policy dismantling: Zero carbon housing in the UK
}

Kirstie O'Neill ${ }^{1}$ and David Gibbs ${ }^{2}$

${ }^{1}$ School of Geography and Planning, Cardiff University, 1.78, Glamorgan Building, King Edward VII Avenue, Cardiff, CF10 3WA.

${ }^{2}$ Department of Geography, Geology and Environment, University of Hull, Hull, HU6 7RX, United Kingdom.

Email

Kirstie O’Neill oneillk1@cardiff.ac.uk

David Gibbs d.c.gibbs@hull.ac.uk

\begin{abstract}
In this paper we examine the failure of the zero carbon homes agenda in the UK and argue that it represents a case of policy dismantling, where a range of policies and programmes have been introduced, revised and then removed by government. We bring together the sustainability transitions literature with the literature on policy dismantling, regime resistance and regime detractors, and suggest that the zero carbon housing agenda in the UK offers useful insights into the politics of sustainability transitions. We identify three phases of policy change, from policy expansion, symbolic dismantling and eventual active policy dismantling. In the conclusions we offer some suggestions on processes of policy dismantling and what this might mean for future sustainability transitions given the significant contributions of buildings to greenhouse gas emissions and the urgent need for rapid low carbon transitions.
\end{abstract}

\section{Introduction}

It is recognised that climate change presents a dangerous and irreversible situation (Dalby, 2019) that requires accelerated transitions (Koehler et al., 2019) and significant change, socially, economically and politically. The sustainability transitions literature has provided a means to explore the potential for major socio-economic shifts towards a more sustainable future (Chatterton, 2016; Sheldrick et al., 2017), although as Feola (in press) notes, the sustainability of sustainability transitions has not always been scrutinised. Much of this research has focused on innovation niches that challenge incumbent regimes e.g. the growth of the renewable energy sector challenging carbon-based energy generation (Araújo, 2014). In policy terms the emphasis has been on how niches can experiment for regime change, and be encouraged and mainstreamed. The literature has, however, much less to say about how policy attempts to mainstream niche innovations might falter or fail. In this paper we discuss the ways that the UK government attempted to mainstream certain forms of niche green building approaches, with the aim of engendering a sustainability transition in the construction industry and changing the UK's building stock. Consequently, we emphasise how 
sustainability transitions can be messy and potentially fail, employing the example of the UK's Code for Sustainable Homes (the Code) and zero carbon housing ( $\mathrm{ZCH}$ ) agenda to explore policy dismantling and the politics of sustainability transitions.

While recent work in the sustainability transitions literature aims to address shortcomings around politics and power in transitions (e.g. Avelino, 2017), suggesting that political science theories might offer useful insights, this work largely focuses on successful transitions (Roberts and Geels, 2018). There is a range of policy theories relevant to transitions theories (Kern and Rogge, 2018), but we focus here on research into policy dismantling (Jordan et al., 2013; Bauer and Knill, 2014), that offers ways to conceptualise how and why sustainability transitions might fail. We synthesise this work with the sustainability transitions literature in our discussion of policy dismantling, as a process where regime resistance and changing government priorities successfully prevent transitions (Hess, 2014). Understanding the politics of transitions is essential to identify how future transitions might encounter challenges and how these might be addressed (Avelino et al., 2016).

Our focus on the green building sector is of key importance for sustainability and climate change, given the role of the built environment in materials consumption and greenhouse gas emissions, through embodied emissions and post-occupancy energy demands. Current UK heating and cooling demands are primarily met by fossil fuels and emissions from buildings account for some $35 \%$ of total GHG emissions, with the residential sector responsible for $23 \%$ and the non-residential sector 12\% (Committee on Climate Change, 2015). The UK's housing stock is widely recognised as being some of the most energy inefficient in Europe (Carrington, 2013), indeed 70\% of the UK's building stock does not meet current energy efficiency standards (Matthew, 2017, emphasis added). Policies to encourage more efficient and sustainable new homes were a core part of previous UK governments' climate change mitigation commitments (Greenwood et al., 2017), including retrofitting policies for existing homes (Better Buildings Partnership, 2010). The green building agenda was also seen as part of a broader low carbon transition (Gibbs and O'Neill, 2015) and a means to stimulate economic growth, upskill the construction sector, and ensure a future-proof housing sector. However, since 2010 these programmes have been successively revised, rewritten and, subsequently, abolished altogether.

Green buildings, of course, have a longer history than UK government attempts to mainstream them in the 2000s. A number of low energy, low impact housing niches emerged from the 1970 s onwards (e.g. Findhorn Eco-Village in Scotland), often as a protest against high levels of consumption and as a means of demonstrating how lower impact alternatives could be achieved. For instance, passive solar design strategies combined with energy efficient devices and renewable energy technologies have been applied in buildings to improve thermal comfort and reduce energy end-use for many years (Butti and Perlin, 1980, in Berry et al., 2014). These often had their origins in countercultural movements, which we see as 'organic niches' that emerged without government support. More recent iterations of green buildings have been more technological in nature and thus more amenable to co-optation by business and policy interests (we see these as 'policy niches'). Examples like BedZed in London were identified as examples of best practice, and were instrumental in influencing government policy on zero carbon building. The idea of 'mainstreaming' was adopted to describe the process of diffusing (radical) innovations from niche projects into wider, more incremental change in the construction industry (Lovell, 2004; 2007). 
Whilst research examining green building and the adoption of green building certification schemes (such as LEED, GreenStar, and the Code for Sustainable Homes) has grown (Greenwood, 2012; Boschmann and Gabriel, 2013; Cidell, 2015; Faulconbridge et al., 2018; Affolderbach and Schulz, 2018), and there is wider interest in how low impact buildings can be part of a low-energy and affordable future (Chatterton, 2016; Pickerill, 2017), there has been little academic attention to the abolition of the schemes and funding programmes supporting green building (see Walker et al., 2016 for an exception). Conceptually, this example of policy dismantling is useful in understanding nicheregime interactions in sustainability transitions and highlights the need for a supportive policy environment to mainstream niche practices. Indeed, despite the abandonment of the UK's green building policies, key actors in policy, business and academia continue to argue that the built environment remains key to a sustainable future and achieving global $\mathrm{CO}_{2}$ emission reduction targets (RIBA 2015b; Jones, 2018) and calls remain for clear, robust and decisive Government policies (Osmani and O'Reilly, 2009; Heffernan et al., 2015; Gibbs and O'Neill, 2015; Walker et al., 2015; CCC, 2018;), to encourage the construction industry to invest in sustainable building, given that this is unlikely to occur voluntarily (Goodchild and Walshaw, 2011; Jones, 2018). The UK's transition to a green building sector has thus stalled in contrast to other national contexts (e.g. Iqbal et al., 2017; Affolderbach and Schulz, 2018).

In the next section we outline the sustainability transitions literature and the emerging engagement with power and politics. We then link this to recent developments in political science that consider the idea of policy dismantling. In subsequent sections we trace the policy changes and processes of dismantling associated with the 'zero carbon housing' agenda in the UK and reactions to these policy changes. In our conclusions we explore what this means for thinking about failure in sustainability transitions and power relations in the intentional dismantling of sustainability policy.

\section{Sustainability Transitions: power, politics and policy dismantling}

\subsection{Sustainability transitions and the absence of politics}

Sustainability transitions theories are concerned with the transformation of technological regimes, and emphasise the role of innovative (technological) niches as a key means of effecting transitions (Rip and Kemp, 1998; Smith, 2003; Geels, 2005; Grin et al., 2010). The Multi-Level Perspective (MLP) (Geels, 2005, 2011), Transition Management (TM) (Shove and Walker, 2007; Loorbach, 2010), and Strategic Niche Management (SNM) (Schot and Geels, 2008; Raven et al., 2010) conceptualise niches as spaces of experimentation where new technologies, policies and practices can emerge that transform regimes towards greater sustainability. Specifically, the MLP aims to encapsulate, and distinguish the relationships between three analytical levels: niches, regimes and landscapes (Rip and Kemp, 1998).

In the MLP, socio-technical niches are seen as distinct from regimes and landscapes, offering 'protected' space where new socio-technical assemblages and practices can be experimented with, and where they can develop without the selection pressures of the regime (cf. Berkhout et al., 2003; Smith and Raven, 2012). Niches can comprise single experiments, or clusters of multiple experiments (Kemp et al., 1998) providing supportive networks and acting as incubators, where radical rather than incremental change can evolve (Geels, 2002; Geels and Schot, 2007; Smith et al., 
2010). New socio-technical configurations at the niche level can offer potential solutions to regime problems, either by conforming to regime conditions, or more radically, challenging and transforming regime practices (Smith and Raven, 2012). Where these developments show promise, system builders work to enrol others into the active construction of further strategic spaces for more dedicated, active forms of protection for innovations, such as policy programmes (Lovell, 2007; Raven et al., 2011; Diaz et al., 2013).

Where innovations are empowered to 'break out' of their protective spaces, this may have farreaching implications for wider institutions, infrastructures and other structural dimensions of the selection environment, making them potentially path-breaking (Raven et al., 2016: 165). Under certain circumstances, niches can replace the extant regime and establish a new regime with its own specific conventions and characteristics (Truffer, 2008). However, niche actors and innovations that are less compatible with the existing regime may experience greater difficulty in breaking through to the mainstream, whereas niche activities that align more closely may be more easily incorporated (Smith, 2003). In the latter case, actors in the current regime may borrow convenient aspects of niche activity, but in the process lose the more transformative, and sustainable, aspects (Smith and Raven, 2012).

The role of power and politics in transitions has received growing attention over recent years (Hoffman, 2013; Partzsch, 2016; Ahlborg, 2017) following earlier critiques (Shove and Walker, 2007; Meadowcroft, 2009), yet calls for further attention to the power and politics of transitions remain (Avelino et al., 2016), especially where such transitions fail. As Meadowcroft (2011) has argued, the decisions, regulations and legislation necessary for transitions are inherently political: policy makers can help transitions breakthrough by allocating resources (Meadowcroft, 2009) and creating supportive environments. In addition, the portrayal of sustainability transitions as "relatively linear and teleological" is problematic (Koehler et al., 2019: 3). Similarly problematic is the underlying normative assumption that such low carbon transitions are desirable (for instance, not all actors may agree), and that policy makers actively want to 'deliberately accelerate' (Roberts and Geels, 2018; Roberts et al., 2018) and implement such transitions. That attempts to mainstream niche practices may, in fact, be unsuccessful tends to be overlooked and it is this lacuna in the literature that we address here.

Geels (2014) has argued that one way to introduce power and politics into the MLP is to conceptualize relations and mutual dependencies between policymakers and incumbent firms as a 'core alliance' at the regime level, which often resists fundamental change. Furthermore, Roberts and Geels (2018: 306) note that "a policy may cause new groups or coalitions to form that oppose it, resulting in its eventual dilution or abandonment", suggesting constant change and competing interests in relation to transitions. In this conceptualisation, policy and market elites work in a multidimensional way to influence a wide range of actors, through dominant discourses to (de)stabilise and reproduce [existing] relations of production and meaning (Levy and Newell, 2002, in Geels, 2014). With regard to transitions, Geels argues that this multi-dimensionality means that existing regime actors can defend themselves and resist transitions in various ways. This is termed 'reinforcive' power i.e. "the capacity of actors to reinforce and reproduce existing structures and institutions" (Avelino, 2017: 508). Thus, the selection environment for niches is not objectively given, but made and remade by the interventions of many actors (Meadowcroft, 2009) and their subjective 
interests. Resistance may take various guises. For instance, de Gooyert et al., (2016: 135) discuss policy resistance as a phenomenon whereby systems may delay, dilute or defeat the very policies designed to improve them (cf. Sterman, 1994). Such policy resistance may arise from multiple sources, including industry, users / practitioners, and cultural norms (de Gooyert et al., 2016).

Further, Fastenräth and Braun (2018) describe active resistance by regime detractors who attempt to preserve their position in the regime. However, there is less emphasis on how policy makers' own attempts to mainstream niche innovations (in tandem with regime detractors such as vested interests in the construction industry), like the $\mathrm{ZCH}$ agenda, can be revised and dismantled to the extent that the form of transition originally envisaged is no longer possible. We argue that this shift in government attitudes represents a process of policy dismantling.

\subsection{Policy dismantling}

One way to address some of the shortcomings in the sustainability transitions literature with regard to politics and power comes from a nascent literature in policy studies that considers how policies may be dismantled. Policy dismantling may offer what Geels (2011) describes as 'auxiliary theory' to deepen understanding of the politics of transitions, in particular how planned transitions fail or stall. In relation to our example of the $\mathrm{ZCH}$ agenda, this small body of literature on 'policy dismantling' is salient. Early work on policy retrenchment in welfare programmes (e.g. Pierson, 1994) suggested that once actors have ventured far down a particular path, they might find it very difficult to reverse course. Indeed, Steinebach and Knill (2017: 431) argue that policy dismantling, in contrast to policy expansion, can result in "painful and burdensome changes and hence to be much more difficult to pursue." Thus, policy is seen to be both stable and difficult to dismantle: Pierson (2004) suggests most policies are remarkably durable with incumbent policy makers being locked in to the policy regime. However, in relation to environmental policy, Bauer et al., (2012), Jordan et al., (2013), Gravey and Jordan (2016), and Steinebach and Knill (2017), find clear evidence of policy dismantling. In contrast to unpopular and politically difficult dismantling to welfare state programmes (Jensen et al., 2014), dismantling in relation to environmental policy has been rather easier to achieve.

Bauer et al., (2012: 206) define policy dismantling as "change of a direct, indirect, hidden or symbolic nature that either diminishes the number of policies in a particular area, reduces the number of policy instruments used and/or lowers their intensity. It can involve changes to these core elements of policy and/or it can be achieved by manipulating the capacities to implement and supervise them." Thus, dismantling is viewed as a complex process, driven by different motivations and actors, and takes multiple forms. Bauer et al., (2012) identify four main forms of dismantling (see Table 1.).

Table 1. Forms of Policy Dismantling.

\begin{tabular}{|l|l|}
\hline Dismantling strategy & Characteristics \\
\hline Dismantling by default & $\begin{array}{l}\text { No adjustment: policy remains static in face of technological, } \\
\text { social or political changes }\end{array}$ \\
\hline Active dismantling & Abolition of policies and / or instruments \\
\hline Dismantling by arena shifting & $\begin{array}{l}\text { Transfer or delegation of responsibilities to different policy scale } \\
\text { or institution }\end{array}$ \\
\hline Symbolic dismantling & $\begin{array}{l}\text { Changes in policy density or intensity. Policies may be relabeled, } \\
\text { albeit with changes in the type of policy focus }\end{array}$ \\
\hline
\end{tabular}

Source: Bauer et al., (2012). 
The type of dismantling strategy selected is affected by prevailing macro conditions, institutional opportunities and constraints and situational factors. Different dismantling approaches affect the degree of resistance encountered and dismantling can represent both the ends, and the means, to achieving change. These different types of dismantling indicate that dismantling is not merely a binary choice between continuation and termination (Bauer et al., 2012). The process of dismantling can offer advantages to some groups while conferring losses for others. Bauer and Knill (2014) explore how dismantling may occur through changes to policy density (expressed in terms of changes in the number of policies and policy instruments) and policy intensity (expressed as the strictness or, as in the case of social policies, generosity of particular policies). In attempting to explain these processes, Bauer and Knill (2014) argue that politicians' behaviour will emerge from the interplay between the things they want (policy achievements, re-election, etc.) and other actors' perceived strategies and external constraints (permanent austerity, international regulatory pressures, technological changes, etc.), and the type of policy affected (see also Steinebach and Knill, 2017). If previous assumptions are undermined, more dramatic policy shifts may be possible (Baumgartner, 2013).

In the policy dismantling literature, there is agreement that the 2008 recession was a key moment for policy reform and dismantling (Bauer et al., 2012), in the UK and beyond (e.g. Jordana, 2014). Jordan et al., (2013) note that one of the many ways in which politicians seek to respond to the pressures of economic austerity is to cut, or even completely remove, public policies that were introduced in better times. Baumgartner et al., (2009, in Baumgartner, 2013) discuss the 'sticky' nature of ideas within policy communities and suggest that reframing ideas can be difficult because experts within policy communities, like other actors, typically have strong attachments and vested interests in the status quo definition of the issue. Such 'stickiness' is likely to affect sustainability transitions, and regime actors will resist changes that challenge their position or undermine their privileges. Nevertheless, the 2008 recession may be seen as a framing event that justified intentional policy change in the UK. Certainly Gravey and Jordan (2016) note a strengthening of the policy dismantling discourse following 2008 , specifically in relation to environmental policy. The ensuing austerity programmes in the UK (and elsewhere) resulted in further loss of momentum in environmental policy (Bürgin, 2015: 503; Čavoški, 2015; both cited in Steinebach and Knill, 2017). Bauer et al., (2012) conclude that reductions in policy intensity were more common than the complete removal of policies (i.e. significant policy density reductions). The example of the $\mathrm{ZCH}$ agenda is then novel in representing a clear case of complete policy removal (dismantling).

In the following sections we demonstrate that the forms of dismantling identified by Bauer et al., (2012) can be employed contiguously, with each round of dismantling reinforcing the last, eventually undermining the whole $\mathrm{ZCH}$ agenda in the UK.

\section{Methods}

Before proceeding to our analysis of policy dismantling of the $\mathrm{ZCH}$ agenda, here we discuss our methods. This paper extends our earlier primary research (2011-2014), which focused on the role of businesses and other institutions developing green building in the UK. This earlier research involved in-depth, semi-structured interviews with businesses and policy makers, focusing on the green economy, of which green building is a part. During this research, the role of government 
environment policy broadly, and the Code specifically, was noted as being important to these businesses. In the time following this research, significant changes to these policies were enacted. As a result, here we shift our focus to attend to the policy challenges and changes affecting green building, rather than looking directly at business experiences. Thus, we develop an analysis of government policy changes (dismantling), based on secondary analysis of policy documents and associated responses. We employ secondary material to trace the developments in relation to the $\mathrm{ZCH}$ agenda, from 2003 to the present. This involved searching for policy statements and media accounts of the $\mathrm{ZCH}$, using search terms including 'Code for Sustainable Homes', zero carbon building, green building and sustainable building. This resulted in over 50 documents being analysed, although not all of these are referenced here. These documents included industry media (e.g. the Architect's Journal, online business sites, news bulletins from the UK Green Building Council (UKGBC) etc.,) and government policies and strategies from bodies like the Intergovernmental Panel on Climate Change (IPCC). These documents were coded for their narratives of green building, policy dismantling and change, noting key actors, building a chronological pattern of policy change since 2003. Our aim is to focus on a single, and recent, case study to uncover the politics of failure in relation to anticipated regime transitions.

\section{Green building in the UK}

\subsection{Policy expansion: An emerging green building agenda, 2003-2010}

The context for the emergence of a green building policy agenda in the UK can be set against a background of growing concern for, and consensus about, climate change (Lovell, 2004; Gillard, 2016). The 2003 White Paper Our Energy Future: Creating a Low-Carbon Economy adopted climate change as a central policy problem (Geels, 2014). It identified the need to improve energy efficiency in buildings, with government pledging to set an example in its own building portfolio (TSO, 2003). It was argued that:

\footnotetext{
"New homes will be designed to need very little energy and will perhaps even achieve zero carbon emissions. The existing building stock will increasingly adopt energy efficiency measures. Many buildings will have the capacity at least to reduce their demand on the [electricity] grid, for example by using solar heating systems to provide some of their water heating needs, if not to generate electricity to sell back into the local network." (TSO, 2003: 18 , emphasis added)
}

This unambitious message was followed with more decisive language from the then Housing Minister, Yvette Cooper, who stated, "We need a complete revolution in the way we design and build our homes..." (Osborne, 2007). As a means to achieve this 'paradigm shift', the Labour government introduced the Code for Sustainable Homes ('the Code') in 2006, intended to provide a "single national standard to guide industry in the design and construction of sustainable homes. It is a means of driving continuous improvement, greater innovation and exemplary achievement in sustainable home building" (DCLG, 2006: 4). The Code used a points system from 1-6 stars, where 1 is the lowest (or 'entry level') and 6 the highest (or 'zero carbon') (see Table 2.1). Rather than focusing solely on the energy or carbon performance of a house, the Code was to take a 'whole home' approach based around nine key design categories (see Table 2.2). Under the Code, a Level 6 
home was to be commensurate with ZCH status, defined as "zero net emissions of carbon dioxide $\left(\mathrm{CO}_{2}\right)$ from all energy use in the home including heating, lighting, hot water and all other energy use" (Panagiotidou and Fuller, 2013: 197). However, the call for a paradigm shift was not prescriptive as to how builders should reach these levels; indeed the Code was meant to encourage innovative responses and cost effective solutions. This open definition caused some initial concern for the construction industry, which advocated a definition of zero carbon development that was technologically feasible, commercially viable (Rydin 2013; Walker et al., 2015), but not so transformative.

Table 2.1. Points required for Levels 1-6 of the Code for Sustainable Homes rating system Table 2.2. Categories of the Code and example typical solutions

\begin{tabular}{|l|c|}
\hline Code levels & Total Point Score \\
\hline Level $1(\star)$ & 36 \\
\hline Level $2(\star \star)$ & 48 \\
\hline Level $3(\star \star \star)$ & 57 \\
\hline Level $4(\star \star \star \star)$ & 68 \\
\hline Level $5(\star \star \star \star \star)$ & 84 \\
\hline Level $6(\star \star \star \star \star \star)$ & 90 \\
\hline
\end{tabular}

\begin{tabular}{|c|c|c|c|}
\hline $\begin{array}{l}\text { Categories of } \\
\text { environmental impact }\end{array}$ & $\begin{array}{l}\text { Points } \\
\text { available }\end{array}$ & $\begin{array}{l}\text { Category } \\
\text { weighting \% }\end{array}$ & $\begin{array}{l}\text { Examples of typical } \\
\text { solutions }\end{array}$ \\
\hline 1. Energy and carbon emissions & 29 & $36.4 \%$ & $\begin{array}{l}\text { Sustainable / recycled materials } \\
\text { Certified timber } \\
\text { Insulation } \\
\text { Natural lighting }\end{array}$ \\
\hline 2. Water & 6 & $9 \%$ & $\begin{array}{l}\text { Rainwater harvesting } \\
\text { Low water sanitary-ware }\end{array}$ \\
\hline 3. Materials & 24 & $7.2 \%$ & $\begin{array}{l}\text { Sustainable materials - lime, } \\
\text { reclaimed / recycled bricks }\end{array}$ \\
\hline 4. Surface water run-off & 4 & $2.2 \%$ & $\begin{array}{l}\text { Porous paving } \\
\text { Rainwater harvesting }\end{array}$ \\
\hline 5. Waste & 7 & $6.4 \%$ & Recycling bins \\
\hline 6. Pollution & 4 & $2.8 \%$ & $\begin{array}{l}\text { Energy efficient heating } \\
\text { Insulation }\end{array}$ \\
\hline 7. Health and welibeing & 12 & $14 \%$ & $\begin{array}{l}\text { Underfloor heating } \\
\text { Ventilation }\end{array}$ \\
\hline 8. Management & 9 & $10 \%$ & Security systems \\
\hline 9. Ecology & 9 & $12 \%$ & $\begin{array}{l}\text { Minimising impact on the } \\
\text { environment - various options }\end{array}$ \\
\hline
\end{tabular}

Source: authors' adaptation, from DCLG (2010).

In order to develop solutions, the construction industry, building professionals, NGOs and policy actors were encouraged to collaborate through the 'Zero Carbon Task Force' and 'Zero Carbon Hub' to define $\mathrm{ZCH}$ and its operationalisation (Greenwood 2012). In creating this new organisation, the government may have been attempting to find solutions through co-action, by building a collective 
group or a 'niche-regime' working towards positive environmental change (cf. Avelino, 2017; Partzsch, 2017). Building a Greener Future (DCLG, 2007) set out the need to build in a way that cuts carbon emissions, and confirmed the 2006 commitment to ZCH and the Code. In this document, the government set out a schedule for energy reductions through the building regulations by $25 \%$ in 2010, and 44\% in 2013, and stated that "zero carbon means that, over a year, the net carbon emissions from all energy use in the home would be zero" (p. 14). All new homes were to be zero carbon from 2016 onwards.

The European Union's 2010 Energy Performance of Buildings Directive (EPBD) (2010/31/EU) reinforced the Code. The EPBD stipulated that from 2020, new houses and buildings should meet the EU definition of a Nearly Zero Energy Building (NZEB):

"'a building that has a very high energy performance... The nearly zero or very low amount of energy required should be covered to a very significant extent by energy from renewable sources, including energy from renewable sources produced on-site or nearby".

The EPBD devolved the responsibility for developing a legislative framework for the delivery of NZEBs to individual member states (Bartiaux et al., 2014). Whilst this was intended to give flexibility for geographically appropriate responses, it resulted in a diverse range of definitions of what constitutes NZEB, and thus confusion (Mlecnik, 2012).

In UK policy terms, the Code was intended to create an opportunity for the building industry to engage with innovative responses to building the kinds of sustainable housing seen in niche developments and as a means for firms to gain market advantage over competitors (DCLG, 2006). It was also intended to give the building industry much greater regulatory certainty and thus underpin the proposed paradigm shift. However, the failure of the Labour government to reach a final and complete $\mathrm{ZCH}$ definition created significant uncertainty for the house-building sector as well as for subsequent governments (Osmani and O’Reilly, 2009; Greenwood et al., 2017).

\subsection{Symbolic dismantling: diminution of the zero carbon homes policy, 2010-2015}

In contrast to the Labour government's period of creating policies on climate change and building, since 2010 these have been subjected to a continual process of erosion and symbolic dismantling. Initially, climate change and the environment was a cornerstone of the Conservative Party's election campaign and in The Coalition: Our Programme for Government, the government promised to 'implement a full programme of measures to fulfil our joint ambitions for a low carbon and ecofriendly economy' (HM Government, 2010: 16). However, it soon transpired that 'the environment' would cause tension in the elected Conservative-Liberal Democrat coalition government (the Coalition), particularly in light of austerity programmes and the (mis)perception that economic growth cannot be compatible with the environment in the transition to a low carbon economy (cf. Carter and Clements, 2015; Gillard, 2016).iii

In 2011, the Coalition revised the ZCH definition without consultation. The original definition stated that net $\mathrm{CO}_{2}$ emissions from all energy used in the dwelling (regulated energy: space and water heating, fixed lighting) as well as net $\mathrm{CO}_{2}$ emissions from use of appliances in homes (unregulated 
energy: televisions, computers, hairdryers) should be zero or better, averaged over a year. However, the 2011 revision omitted appliances (unregulated energy) from the definition, following pressure from the housing industry (McLeod et al., 2012), thus weakening the impact. According to Walker et al., (2015: 7) this re-specification allowed approximately a third of emissions to 'leak out' from the carbon calculation, and led to the WWF representative resigning in protest from the Zero Carbon Task Force, arguing that 'this policy can now no longer be defined as "zero carbon"' (WWF, 2011). The changes to the classification of 'energy' in the Code represent symbolic dismantling, changing the strength of the Code and suggesting its future demise. The Coalition did maintain a formal commitment to the $2016 \mathrm{ZCH}$ target throughout their term, but a definition of the target was still not forthcoming (Greenwood et al., 2017).

In 2013, the Coalition undertook a Housing Standards Review Consultation (DCLG, 2013), which proposed 'winding down' the Code as part of the Government's aims to simplify building standards and to get rid of 'red tape', both of which were supposedly hampering the industry. A key element in this policy shift came through changes to Part $L$ of the Building Regulations, concerned with energy performance targets for homes and other buildings (Gibbs and O'Neill, 2015). The subsequent Infrastructure Billiv proposed downgrading the ZCH standard from Level 6 to Level 5 of the Code, and introduced Allowable Solutions (AS) whereby developers would be permitted to build to Level 4 by drawing on AS to achieve Level 5. The AS offered developers a choice of (1) providing renewable energy on site; (2) paying towards renewable energy off-site; or (3) paying into a carbon offsetting scheme. Controversially, the government exempted sites of 10 units or less, or a maximum size of 1000 square metres of floor space, from the AS element of the ZCH standard (Pearson, 2014). While AS could potentially encourage better integration of energy and building policies, when consulted by government on zero carbon homes policy, house-builders preferred the third option - to pay into a fund that invests in off-site carbon abatement projects (DCLG, 2014). Furthermore, most builders preferred the lower end of such payments, arguing that $£ 36 /$ tonne of carbon was more appropriate than $£ 90 /$ tonne, despite the higher rate being preferred by other consultation respondents. As such, house builders effectively had a buy-out clause via third parties to deliver zero carbon outcomes through carbon offsetting while continuing to build to less stringent energy standards, thus further watering down the original zero carbon commitment. This lessened the impact upon the mainstream building regime, following lobbying by the sector attempting to preserve the extant regime (Panagiotidou and Fuller, 2013), suggesting elite influence on policy directions. Combined, the removal of the need to account for unregulated energy and the introduction of AS reduced the requirements for $\mathrm{ZCH}$ to between Code levels 4 and 5 (Heffernan et al., 2015: 25). These changes occurred despite evidence of both the importance of buildings for a low carbon future (IPCC, 2014, p. 677), and that new homes were failing to meet the then current definition of zero carbon (UKGBC, 2008: 5).

\subsection{Active dismantling: green building in a Conservative policy framework, 2015-onwards}

In the 2015 general election the UK elected a Conservative government, and in 2016, a new Prime Minister, Theresa May, replaced David Cameron who resigned after the 'Brexit' referendum. In 2015 the Conservative government published Fixing the Foundations: Creating a More Prosperous Nation, setting out how it would achieve continued economic growth through increased productivity. This report stated that it would continue: 
"to reduce net regulation on house-builders. The government does not intend to proceed with the zero carbon Allowable Solutions carbon offsetting scheme, or the proposed 2016 increase in on-site energy efficiency standards, but will keep energy efficiency standards under review, recognising that existing measures to increase energy efficiency of new buildings should be allowed time to become established" (HM Treasury, 2015: 46).

This saw a shift towards a much more vague commitment to green building, which was combined with other examples of actively dismantling environmental policy. The government removed the tax exemption on renewable energy companies (Vaughan, 2017), and on community energy schemes (Gani, 2015). Furthermore, on the $23^{\text {rd }}$ July 2015 the then Climate Change Secretary ${ }^{v}$ Amber Rudd announced that the government would no longer fund the Green Deal and that there was no programme to replace it. Households and developers were therefore no longer incentivised to implement energy saving measures or insulation works to improve their home's heat retention, beyond those personally motivated to do so.

The Code itself was abolished in July 2015. Level 6 of the Code was supposed to become mandatory for all new homes in 2016, but in abolishing the Code, and adopting Code level 4 as the new regulatory level in the revised Building Regulations, the government effectively (further) reduced the minimum standards that must be met. The Building Regulation changes were viewed by government as a less bureaucratic and easier to understand route to achieving zero carbon homes and claimed they represented a more efficient way of achieving the same ends. However, successive revisions to the Building Regulations have been far from unbureaucratic (Gibbs and O'Neill (2015). Furthermore, Part $L$ of the Building Regulations (relating to energy) would not be revised in the foreseeable future. Additionally, funding for the Zero Carbon Hub was withdrawn as part of wider austerity-driven funding cuts; it subsequently ceased operation altogether in March 2016, when industry funding was also withdrawn.

Following the abolition of the Code and a raft of environmental policies related to buildings and renewable energies, the Conservative government issued a number of statements and initiatives that related to sustainable building, but which reinforced the government's vision for economic growth and technological innovation. The focus is on house building as a core part of (growing) the economy, instead of as a mechanism for providing sustainable and future-proofed homes, and reducing the environmental impacts of construction, thus continuing to prioritise growth logics over environmental concerns. Further, rather than offering the clear and consistent policy that many in the green building industry called for, these statements represented a vague and toothless approach to delivering an important aspect of the UK's response to climate change and delivering sustainable homes. A speech by the then Prime Minister Theresa May reinforced the government's commitment to innovation and economic growth, and the central role of technology:

\footnotetext{
"Meeting this challenge will drive innovation and higher standards in the construction sector, helping it to meet our ambitious homebuilding targets and providing more jobs and opportunity to millions of workers across the country...We will use new technologies and modern construction practices to at least halve the energy usage of new buildings by 2030. By making our buildings more energy efficient and embracing smart technologies, we can
} 
slash household energy bills, reduce demand for energy, and meet our targets for carbon reduction." (in Mace, 2018, our emphasis)

Halving the energy use of new buildings by 2030 is a much less demanding (and delayed) ambition than that previously embodied in the Code. Her speech built on earlier announcements, including Greg Clark's vi (2017) announcement on plans to commercialise technologies capable of building energy-efficient, cost-effective housing and infrastructure. Thus, the government paid lip service to the $\mathrm{ZCH}$ agenda whilst removing legislation and incentives, moving towards a neoliberal and voluntaristic technological and industry-led approach. Industry responses criticised the absence of clear legislation. For example, Julie Hirigoyen of the UKGBC, argued that 'the Government's legislative landscape is in danger of locking in carbon emissions for future generations. New homes will need expensive retrofit measures in future if we're to meet our ambitious reduction targets' (Mark, 2016), reflecting a view that a strong state position is required to make difficult decisions in relation to buildings and climate change.

Finally, a new standard developed by the BRE, the Home Quality Mark (HQM), aimed to foster consumer engagement through a focus on criteria such as health and well-being which ZCH can potentially promote. However, restrictions on local authority powers to set standards through planning conditions, and industry fatigue regarding repeated changes to codes and standards (Gibbs and O'Neill, 2015), suggest that uptake of a measure like the HQM is likely to be limited. Further, this continues to place the responsibility on consumers, who are viewed as rational economic actors rather than as citizens (see Shove, 2010, for a critique), and absolves government and industry from action. In consequence, as there is no one clear replacement for the Code, it seems that, somewhat paradoxically, the initial Housing Standards Review, with its goal of 'streamlining,' could result in a variety of different voluntary standards being adopted across the country. There is a danger this could create more confusion and uncertainty for industry of the kind the Review aimed to prevent (Greenwood et al., 2017: 496), as well as geographically uneven patterns of sustainable building.

\subsection{Summary of ZCH policy dismantling}

We have discussed the creation of a policy agenda on low carbon homes and its subsequent dismantling. This 'dismantling' has occurred through successive strategies and over a fairly rapid timeframe. Moving from policy creation in 2003-2006, subsequent governments have changed the nature of the policy agenda by symbolic dismantling, revising definitions and what was covered by associated policies, and then actively dismantling the ZCH agenda from 2015 onwards. Such policy dismantling and significant swings in government policy have negatively affected the green building sector in the UK (McNeil, 2016), and led to uncertainty over employment and investment risk in the green building sector (Cumming and Zahra, 2016). Following this dismantling, few measures remain in the UK to encourage innovation and implementation amongst either homeowners or developers in relation to green building. It has been argued that the 2015 Conservative Government heralded the worst period for environmental policy in over 30 years, based on an anti-environment ideology which views ecological goals as interfering with the market, increasing costs and as being against the interests of people (Juniper, 2015). The Government justified this by a need to concentrate on an economic growth agenda, a frequently employed argument in environmental policy dismantling during times of recession (Bauer et al., (2012). This despite evidence that the UK's low carbon sector 
employed 432,000 people and produced a turnover in excess of $£ 77$ billion in 2015: greater than car and steel manufacturing (Harvey, 2017).

From its inception, the Code was contentious: some vii argued it should become obligatory (some UK local authorities independently incorporated it into their supplementary planning requirements ${ }^{\text {viii)}}$ ), with others, ultimately successfully, arguing that it was unnecessarily complex and burdensome. In addition, Walker et al., (2015: 10) question why an existing standard - such as 'passive house' ix (Mueller and Berker, 2013), the parameters of which were much more established - was not adopted instead of a vague and contentious concept of $\mathrm{ZCH}$. Moreover, the collaborative process envisaged for reaching a ZCH definition undoubtedly led to constant politicking and giving in to industry advocacy to diminish the scale of change involved (Greenwood, 2012). Neither the 'Zero Carbon Task Force' nor the 'Zero Carbon Hub' was effective in creating a coalition to support and enact the political conditions for a transition to occur. However, whilst many have acknowledged that the Code and ZCH policy was less than perfect, it did, in principle, meet the criteria for good policy implementation: it set an ambitious target above existing standards, was set in advance, and identified a pathway to achieve the $\mathrm{ZCH}$ standard, as well as connecting to legislative behemoths like the Climate Change Act 2008. While Code certification involved administrative costs, it provided a common industry language and audit process for addressing energy and sustainability that promoted learning and embedded change (Greenwood et al., 2017).

It can be argued that the Code encouraged a particular set of responses to green building requirements that favoured particular technological niche solutions (the 'policy niche') that the existing system could readily accommodate (Gibbs and O'Neill, 2015), thus posing a limited degree of disruption, and ignored both the potential of more radical green building approaches based on natural and local materials, such as straw or hemp (the 'organic niche'), or other technological solutions such as passive house which required a high level of technical skills. Certainly, there is a general reluctance, especially within the construction industry, to build and retrofit to more radical sustainable and zero carbon standards (Gibbs and O'Neill, 2015; Jones, 2018). Initial policy aspirations seemed unable to compete with the fast-track 'minimum capital cost-led' construction industry focused on building significant numbers of new houses in the UK. A resistance to change by the 'big' construction firms is thus a major barrier to the transition to a zero carbon built environment (Jones, 2018: 568). Certainly, opposition to the Code did come from the dominant Home Builders Federation (HBF) as a key 'policy detractor' (Fastenräth and Braun, 2018), which lobbied government for a reduction in the regulations (Harper, 2016).

The HBF argued that scrapping the ZCH commitment was 'a sensible move' and claimed that 'the UK is already building some of the most energy efficient homes in the world under the current exacting standards. Homes built today are 30 - 50\% more energy efficient than existing homes, saving buyers hundreds of pounds a year on energy bills' (Harrabin, 2015). Given the UK Conservative government's strong alignment with neoliberal political ideologies it is perhaps no surprise that it was sympathetic to the views of lobbies such as the HBF (cf. Geels, 2014). For such policy detractors, removal of the Code was justified as 'streamlining,' arguing that energy and water efficiency measures in the Building Regulations had been strengthened (Greenwood et al., 2017: 495). 
However, the HBF represents only one part of the building sector, which encompasses a multiplicity of building approaches by different actors (Gibbs and O'Neill, 2014; O'Neill and Gibbs, 2016). By contrast to the $\mathrm{HBF}$, the UKGBC and the $\mathrm{AECB}^{\mathrm{x}}$ wrote to the Chancellor of the Exchequer and other government departments when the removal of the policy was announced, highlighting a different industry viewpoint that emphasised:

"a broad consensus in support of the zero carbon policy, which was designed to give industry the confidence it needs to invest and innovate, in order to drive higher energy efficiency standards and low carbon energy solutions."

This open letter, with almost 250 signatories from across the (sustainable) construction industry, went on to argue that:

"[s]ince the policy was first launched eight years ago, business has invested heavily in preparing for future standards. This sudden U-turn has undermined industry confidence in Government and will now curtail investment in British innovation and manufacturing in low carbon products and services. There is no evidence to suggest it will increase housing supply or boost productivity."

These other actors in the house-building industry, often more strongly aligned with green building policies, argued that removing the Code was 'short-sighted, unnecessary, retrograde and damaging to the house building industry' (UKGBC, in Oldfield, 2015). The Committee for Climate Change has equally argued for the Code to be reinstated (CCC, 2019) and for a clear and consistent national policy (Greenwood et al., 2017). Further, powerful industry organisations, such as the Royal Institute of British Architects (RIBA), urged the government to reconsider the zero carbon decision (RIBA 2015a; 2015b), and to reinstate it. However, despite appeals from this range of actors involved with green building the policy was effectively dismantled and replaced by a vague set of government aspirations. In the following section of this paper, we link the changes we have outlined in relation to green building to ideas around the intentional dismantling of sustainability policy.

\section{Policy dismantling, power and sustainability transitions}

Over the last fifteen years, then, there has been a significant degree of churn in UK government policies relating to the concept and implementation of green building and $\mathrm{ZCH}$. The Labour Government introduced a range of policies designed, in principle, to encourage a shift to zero carbon building as part of a wider low carbon transition (HM Government, 2009a; 2009b). However, while the then Labour government initially sought to achieve zero carbon building through a set of comprehensive policies for the building sector, these lacked consistent application and have been subject to amendment by subsequent administrations in favour of construction methods that conform to the dominant building regime, developer freedoms, and free market growth. When Labour were defeated in the 2010 UK General Election, it was anticipated that many of the 'green' policies and Acts they had established would remain intact as the Coalition government claimed it would be the 'greenest government ever' i.e. that these policy ideas would remain 'sticky' (cf. Baumgartner et al., 2009). However, since 2010, the commitment to ZCH has come under attack. Following the election of a Conservative government in the 2015 UK General Election there was a 
rapid dismantling of these policy frameworks. This contrasts sharply with Labour's original policy aim of a paradigm shift and mainstreaming (some forms of) green building niche practices.

This account of the successive revisions and U-turns to the $\mathrm{ZCH}$ agenda tells a story about policy dismantling. Our argument is that combining insights from the policy dismantling literature with sustainability transitions research helps to focus attention on the power and politics of failed transitions. In particular it helps us think about the power embedded in sustainability transitions, and thus why such transitions are far from guaranteed or straightforward. The case of the Code and $\mathrm{ZCH}$ also focuses attention on changing government policies and priorities, rather than assuming that governments consistently aim to 'deliberately accelerate' transitions or that policies are simply blocked by incumbent actors.

From the outset, it may be that the Labour government was not fully committed to this agenda, and did not invest the required resources in defining zero carbon, nor experimenting with new technologies and approaches to green building. Moreover, the prevailing political ideology of the time favoured a market-led voluntary approach, rather than providing a specific definition of $\mathrm{ZCH}$ that would be enshrined in policy and implemented by housebuilders. The Committee on Climate Change (2018) has, recently, criticized this approach to the built environment, arguing that 'concrete' policies are required to meet statutory emissions targets. While the lack of a clear definition was intended to create innovation and radical thinking, in reality it created stagnation and confusion, thus limiting the expansion and variety of green building developed. The creation of the Zero Carbon Task Force and Hub may have been intended to create a coalition (Roberts et al., 2018) to support a green building transition, but governments failed to build strong alliances with those groups, such as RIBA and the AECB, which could have supported the policies.

Instead, industry actors/'policy detractors' like the HBF, as well as some large-scale house-builders, took advantage of an opportunity to attack and unpick this agenda, so that the government's lack of commitment enabled these motivated actors and lobbyists to successfully campaign for the removal of the policy. These actors were also more closely aligned with the ideology of subsequent Conservative governments and thus acted as a coalition with some elements of government to block a transition. Acting in this way, organisations like the HBF were creating competing visions and antinarratives (Raven et al., 2016: 177) that reinforced the incumbent practices of the mainstream construction sector. Kenis et al., (2017) discuss the role of primary visions ('Leitbilder' in MLP terms) in creating a clear consensus of a desired future (such as the Code and the $\mathrm{ZCH}$ agenda) and competing secondary visions, such as deeper green practices (e.g. natural building practices, or Passivhaus) involving different pathways towards a desired future. Stimulating such Leitbilder is a key mechanism for changing discourses that promote or inhibit certain practices in society. However, we argue there are additional actor groups whose visions do not work towards this desired future, but rather challenge, undermine and destabilise it to promote futures that preserve the privileges of elite actors who benefit under capitalist regimes. The lack of a convincing 'primary' vision has led to a situation where these powerful actors have been able to maintain their positions and privileges, even though these are at odds with the need to act on climate change. In our example, UK governments did not counter the arguments of incumbents or indeed were already captured by their arguments (e.g. some Conservatives and major housebuilders). Additionally, the 
initial coalition building efforts, such as the Zero Carbon Hub, were weak and enabled incumbents to subvert the agenda.

From a transitions perspective, shifts in the broader 'landscape', particularly in the form of the financial crisis and subsequent austerity programmes, also acted to foreclose the possibility of windows of opportunity to change the regime, which had initially been opened up by policy developments including the 2008 Climate Change Act and the low carbon transition agenda. This acted as a block to mainstreaming niche ideas about green building, especially the 'greener' forms of green building, and the abandonment of policies aimed to mainstream (some) niche practices, with the green building agenda being replaced with vague policy indicators that left $\mathrm{ZCH}$ subservient to 'bigger' issues like economic growth (CCC, 2018). The notion of the 'red tape review' further reinforced the idea that green building policies were an impediment to economic growth, despite evidence suggesting that the green economy was more buoyant than other sectors (Harvey, 2017).

Moments of crisis and disruption (like the 2008 financial crisis and ensuing 'austerity project') can therefore lead to significant policy change by prompting critical reflection on the status quo and heightening demand for a proactive response. In the case of green building and energy consumption, an alternative window of opportunity was created for entrepreneurial individuals within government and the private sector to argue for the dismantling of policy and a focus on energy security and affordability (Gillard et al., 2017). Windows of opportunity can thus impede as well as accelerate transitions. Indeed, Gillard et al., (2017, citing Carter and Jacobs, 2014) argue that the UK government's climate change policies were already faltering and being pursued without effective coordination across government departments and sectors. Combined with the 2008 financial crisis, which placed significant pressure on the Government to reduce the budget deficit, and with departments like the Treasury becoming increasingly 'hostile' towards climate policies (Gillard, 2016: 32), policies like the $\mathrm{ZCH} /$ Code were easy targets to reduce government spending. While the government wanted to speed up house building amid concerns about housing affordability and economic recovery, the $\mathrm{ZCH}$ agenda was viewed as a threat to productivity rather than an opportunity to place the UK at the forefront of green building and retrofitting.

It can be argued that policies related to $\mathrm{ZCH}$ were perhaps never really about mainstreaming the green building niche, but rather appropriating components of the niche that focused on the role of profitable technological advances that could ameliorate climate change impacts without requiring politically 'unacceptable' ideas like social change. In this vein, we have conceptualised two related but distinct niche forms: a 'policy niche' focused on incremental and technological modifications to the mainstream construction regime, and an 'organic niche' consisting of original pioneers with more transformative visions, whose actors espouse practices like low impact building and who are likely to practice sustainable building regardless of policy programmes. The process of policy dismantling means that nothing much has changed for the organic niche: it remains comparatively small scale and with limited take-up, except by committed individual house-builders and -buyers. For example, the AECB developed its own CarbonLite programme, outside of the $\mathrm{ZCH}$ debate, designed to produce low carbon and low energy buildings. However, such strategies effectively mean that actors and firms remain within the organic niche, rather than engaging with the mainstream. Such examples can demonstrate the potential of more radical forms of green building and stimulate change in house building (e.g. Berry et al., 2014; Chatterton, 2016), albeit at a different scale and speed to more 
mainstream policy programmes. However, while they may produce high quality buildings in environmental terms, these are likely to be one-off buildings or small-scale developments that comprise local socio-technical projects rather than challenging mainstream practice (Schot and Geels, 2008; Smith and Raven, 2012), especially given that even the more technologically-oriented 'policy niche' failed to gain traction with the major house-builders.

In sum, based on the challenges faced in our example, where an attempt to instigate a transition encountered multiple forms of dismantling, we suggest that a range of conditions need to be met to improve the success of sustainability transitions:

- An initial identification of tensions or bottlenecks in the regime that niche innovations can resolve by industry actors and policy makers;

- The encouragement and development of public pressure or demand for niche innovations like sustainable housing;

- Subsequent discursive shifts in public opinion and/or pressures which can guide and justify policy makers' actions;

- Developing commitment by construction firms and other institutions to motivate change;

- Long-term commitment by influential policy makers to ensure policies and programmes can endure the longue durèe necessary to address complex issues like climate change.

This set of wide-ranging conditions that need to come together simultaneously is difficult to achieve and highlights the need for strong government commitment to help guide other actors and garner their support. As our example shows, even where some elements exist (e.g. pressure from some sections of industry) and where innovations that are compatible with the regime are available (e.g. solar panels), success is not guaranteed.

\section{Conclusions}

In conclusion, perhaps we should not be surprised that the proposed shift to zero-carbon housing has encountered resistance, and that many different actors find it difficult to envisage how the last two centuries' dependency on fossil fuels can be reoriented given the short timeframe required to avoid serious climate-change impacts (Jones, 2018). This suggests that government/state action is required to support such a grand transformation, and that we cannot rely on market forces alone to deliver this scale of change (CCC, 2019). Business as usual will not meet the political or climate change targets, and is likely to deliver only small-scale and incremental change, rather than the systemic transformation required (cf. Jones 2018). While excitement and enthusiasm can accompany particular local examples of low (or zero) carbon living, moving at speed and at scale needs a state prepared to steer change (however imperfectly) towards transition (Walker et al., 2016). The $Z C H$ agenda was one clear way that the UK had attempted to do this. The state's ability to attract and govern investment choices, as well as regulate and set performance standards is particularly important for those infrastructures that circumscribe, through their obdurate materiality, opportunities for the shared, everyday reproduction of low-carbon living (Walker et al., 2016). Further, the state can shape associated policies and practices relating to creating instability in the fossil fuel regime, such as removing subsidies. If government does not actively promote this, as an equitable right for all rather than a problematically individualised and privatised new form of luxury, 
low carbon living remains unlikely to be achieved at scale, or for those most in need of safe, decent and sustainable homes.

Successful sustainability transitions require the ability to envisage a more sustainable future, involving the need to break with incumbent systems (Hoffman, 2013). This UK example suggests that the then government and the mainstream building sector were not (yet) ready to embrace such an alternative future, and rather than explore deep green practices from the green building niche (such as straw bale or hemp building, smaller building envelopes and lower levels of material consumption) these actors looked to technological solutions that required minimal system change and which did not challenge their power. This example of policy dismantling suggests that attempted transitions encounter resistance from multiple actors, working at various scales and over differing time periods. Given this, it is imperative that future research firmly focuses on the politics of transitions, as well as the spatiality and temporality of transitions, all of which may interact to facilitate or hinder such transitions. Our case study of the $\mathrm{ZCH}$ agenda clearly illustrates the multiple and complex ways that attempts to mainstream niche innovations, even those that align more closely with the regime, can experience pressures which affect their success. Our attempt here is one way of addressing the politics of transitions, synthesising two theoretical approaches for the first time. Future research might cover questions such as how regime and niche actors' visions differ, how other political science frameworks can offer insights (for instance, Kingdon's (1984) multiple streams approach), as well as examples of success or failure of niche innovation diffusion and the conditions that led to success or failure. The spatial variations of such transitions through national comparisons would also offer a fruitful research direction. It is by understanding both successes and failures that future transitions can better respond to what is increasingly seen as a 'climate emergency'.

\section{Acknowledgments}

We are grateful to three anonymous reviewers for improving the paper and pushing us to improve this paper significantly. We would also like to thank Helen Coulson for helpful comments on an earlier draft, and Esteve Corbera for editorial advice. All errors remain ours. 


\section{References}

Affolderbach, J., and Schulz, C., (eds) (2018) Green Building Transitions: Regional Trajectories of Innovation in Europe, Canada and Australia, Springer, Cham.

Araújo, K., (2014) The emerging field of energy transitions: Progress, challenges, and opportunities, Energy Research and Social Science, 1, pp. 112-121.

Avelino, F., (2017) Power in sustainability transitions: Analysing power and (dis) empowerment in transformative change towards sustainability, Enviromental Policy and Governance, 27, pp. 505-520.

Avelino, F., Grin, J., Pel, B., and Jhagroe, S., (2016) The politics of sustainability transitions, Journal of Environmental Policy and Planning, 18(5), pp. 557-567.

Bartiaux, F., Gram-Hanssen, K., Fonseca, P., Ozolina, L., and Haunstrup Christensen, T., (2014) A practice-theory approach to homeowners' energy retrofits in four European areas, Building Research \& Information, 42(4), pp. 525-538.

Bauer, M.W., and Knill, C., (2014) A Conceptual Framework for the Comparative Analysis of Policy Change: Measurement, Explanation and Strategies of Policy Dismantling, Journal of Comparative Policy Analysis: Research and Practice, 16(1), pp. 28-44.

Bauer, M.W., (2012) Dismantling Public Policy: Preferences, Strategies and Effects, Oxford University Press, Oxford.

Baumgartner, F.R., (2013) Ideas and policy change, Governance, 26(2), pp. 239-258.

Baumgartner, F.R., Berry, J.M., Hojnacki, M., Kimball, D.C. and Leech, B.L., (2009) Lobbying and Policy Change: Who Wins, Who Loses, and Why. Chicago: University of Chicago Press.

Berkhout, F., Smith, A., and Stirling, A., (2003) Socio-technological regimes and transition contexts, SPRU, University of Sussex.

Berry, S., Sharp, A., Hamilton, J., and Killip, G., (2014) Inspiring low-energy retrofits: the influence of 'open home' events, Building Research \& Information, 42(4), pp. 422-433.

Better Building Partnership (2010) Low Carbon Retrofit Toolkit: A Roadmap to Success, London.

Boschmann, E., and Gabriel, J., (2013) Urban sustainability and the LEED rating system: Case studies on the role of regional characteristics and adaptive reuse in green building in Denver and Boulder, Colorado, Geographical Journal, pp. 1-13.

Bürgin, A., (2015) 'National binding renewable energy targets for 2020, but not for 2030 anymore: why the European Commission developed from a supporter to a brake-man', Journal of European Public Policy, 22(5),pp. 690-707. 
Carrington, D., (2013) Britain's damp, leaky homes among Europe's most costly to heat, The Guardian, https://www.theguardian.com/environment/damian-carrington-blog/2013/nov/29/ukhomes-most-expensive-heat-eu-fuel-poverty, (accessed 16 March 2018).

Carter, N., and Clements, B., (2015) From 'greenest government ever' to 'get rid of all the green crap': David Cameron, the Conservatives and the environment, British Politics, 10(2), pp. 204-225.

Carter, N., and Jacobs, M., (2014) Explaining radical policy change: the case of climate change and energy policy under the British Labour Government 2006-10. Public Administration, 92, pp. $125-141$.

Čavoški, A., (2015) 'A post-austerity European Commission: no role for environmental policy?', Environmental Politics, 24(3), pp. 501-05.

Chatterton, P., (2016) Building transitions to post-capitalist urban commons, Transactions Of The Institute Of British Geographers, 41, pp. 403-415.

Cidell, J., (2015) Performing leadership: municipal green building policies and the city as role model, Environment and Planning C, 33(3), pp. 566-579.

Committee on Climate Change (2019) UK Housing: Fit for the Future? Committee on Climate Change.

Committee on Climate Change (2018) Reducing UK emissions: 2018 progress report to parliament, CCC: London.

Committee on Climate Change (2015) Reducing emissions and preparing for climate change: 2015 Progress Report to Parliament, CCC: London.

Cumming, D.J., and Zahra, S.A., (2016) International Business and Entrepreneurship Implications of Brexit, British Journal of Management, 27(4), pp. 687-692.

Dalby, S., (2019) Bordering sustainability in the Anthropocene, Territory, Politics, Governance, DOI: 10.1080/21622671.2018.1559758.

DCLG (2014) Next Steps to Zero Carbon Hones - Allowable Solutions, Government Response and Summary of Responses to the Consultation, London: DCLG.

DCLG (2013) Housing Standards Review: Consultation, London: DCLG.

DCLG (2010) Code for Sustainable Homes: Technical Guide, Department for Communities and Local Government, DCLG, London.

DCLG (2007) Building a Greener Future: Policy Statement, Department for Communities and Local Government, DCLG, London. 
DCLG (2006) Department for Communities and Local Government (2006a) Code for Sustainable Homes: A Step-change in Sustainable Home Building Practice, Wetherby: DCLG.

de Gooyert, V., Rouwette, E., van Kranenburg, H., Freeman, E., and van Breen, H., (2016)

Sustainability transition dynamics: Towards overcoming policy resistance, Technological Forecasting and Social Change, 111, pp. 135-145.

Diaz, M., Darnhofer, I., Darrot, C., Beuret, J.E., (2013) Green Tides in Brittany: what can we learn about niche-regime interactions, Environmental Innovation and Societal Transitions, 8, pp. 62-75.

DfT (2015) Infrastructure Act, London: UK Government.

Fastenräth, S., and Braun, B., (2018) Ambivalent urban sustainability transitions: Insights from Brisbane's building sector, Journal of Cleaner Production, 176, pp. 581-589.

Faulconbridge, J., Cass, N., and Connaughton, J., (2018) How market standards affect building design: The case of low energy design in commercial offices, Environment and Planning A, 50(3), pp. 627650.

Feola, G., (in press) Capitalism in sustainability transitions research: Time for a critical turn? Environmental Innovations and Societal Transitions, https://doi.org/10.1016/j.eist.2019.02.005

Gani, A., (2015) Government to cut tax relief for community green energy schemes https://www.theguardian.com/environment/2015/oct/28/government-subsidy-cuts-put-greenenergy-companies-at-risk

Geels, F.W., (2014) Regime Resistance against Low-Carbon Transitions: Introducing Politics and Power into the Multi-Level Perspective, Theory, Culture and Society, 31(5), pp. 21-40.

Geels, F.W., 2011. The multi-level perspective on sustainability transitions: responses to seven criticisms, Environmental Innovation and Societal Transitions, 1, pp. 24-40.

Geels, F.W., (2005) Technological Transitions and System Innovations: A Co-evolutionary and Sociotechnical Analysis, Cheltenham: Edward Elgar.

Geels, F., (2002) Technological transitions as evolutionary reconfiguration processes: A multi-level perspective and a case study, Research Policy, 31(8-9), 1257-1274.

Geels, F., and Schot, J., (2007) Typology of socio-technical transition pathways, Research Policy, 36, 399-417.

Gibbs, D.C., and O'Neill, K.J., (2015) Building a Green Economy? Sustainability Transitions in the UK Building Sector, Geoforum, 59, pp. $133-141$.

Gibbs, D.C., and O'Neill, K.J., (2014) Rethinking Sociotechnical Transitions and Green Entrepreneurship: the Potential for Transformative Change in the Green Building Sector, Environment and Planning A, 46(5), pp. 1088-1107. 
Gillard, R., (2016) Unravelling the United Kingdom's climate policy consensus: The power of ideas, discourse and institutions, Global Environmental Change, 40, pp. 26-36.

Gillard, R., Gouldson, A., Paavola, J., and Van Alstine, J., (2017) Can national policy blockages accelerate the development of polycentric governance? Evidence from climate change policy in the United Kingdom, Global Environmental Change, 45, pp. 174-182.

Gravey, V., and Jordan, A., (2016) Does the European Union have a reverse gear? Policy dismantling in a hyperconsensual polity, Journal of European Public Policy, 23(8), pp. 1180-1198.

Greenwood, D., Congreve, A., and King, M., (2017) Streamlining or watering down? Assessing the 'smartness' of policy and standards for the promotion of low and zero carbon homes in England 2010-15, Energy Policy, 110, pp. 490-499.

Greenwood, D., (2012) The challenge of policy coordination for sustainable sociotechnical transitions: the case of the zero-carbon homes agenda in England, Environment and Planning C: Government and Policy, 30, 162-179.

Grin, J., Rotmans, J., and Schot, J., (2010) Transitions to Sustainable Development New Directions in the Study of Long Term Transformative Change, Routledge, London.

Goodchild, B., and Walshaw, A., (2011) Towards zero carbon homes in England? From inception to partial implementation, Housing Studies, 26, pp. 933-949.

Harrabin, R., (2015) Designers create the 'impossible' zero-carbon house http://www.bbc.co.uk/news/science-environment-33544831 (accessed 16 March 2018).

Harper, A., (2016) Briefing Paper: Energy and Sustainability Standards in Planning in England available at: https://www.greenbuildingstore.co.uk/wp-content/uploads/Briefing-Energy-SustainabilityStandards-in-Planning-councils-October-2016.pdf (accessed 12 November 2017).

Harvey, F., (2017) UK needs government backing to unlock billions in green business, says industry, The Guardian https://www.theguardian.com/environment/2017/jun/04/uk-needs-governmentbacking-to-unlock-billions-in-green-business-says-industry (accessed August 2018)

Heffernan, E., Pan, W., Liang, X., and de Wilde, P., (2015) Zero Carbon Homes: Perceptions from the UK Construction Industry, Energy Policy, 79, pp. 23-26.

Hess, D.J., (2014) Sustainability transitions: A political coalition perspective, Research Policy, 43, pp. 278-283.

H.M. Government (2010) The coalition: Our programme for government, https://assets.publishing.service.gov.uk/government/uploads/system/uploads/attachment data/file /83820/coalition programme for government.pdf (accessed 6 April 2018). 
HM Government (2009a) The UK Low Carbon Transition Plan, Norwich: TSO.

HM Government (2009b) The UK Low Carbon Industrial Strategy, London: DBIS/DECC.

HM Treasury (2015) Fixing the foundations: Creating a more prosperous nation, London: UK Government.

Hoffman, J., (2013) Theorizing power in transition studies: the role of creativity and novel practices in structural change, Policy Science, 46, pp. 257-275.

Iqbal, M.I., Himmler, R., and Gheewala, S.H., (2017) Potential life cycle energy savings through a transition from typical to energy plus households: A case study from Thailand, Energy and Buildings, 134, pp. 295-305.

IPCC (2014) Summary for Policymakers, Climate Change: Fifth Assessment Report. Cambridge University Press: New York.

Jensen, C., Knill, C., Schulze, K. and Tosun, J., (2014) Giving less by doing more? Dynamics of social policy expansion and dismantling in 18 OECD countries, Journal of European Public Policy, 21(4), pp. 528-548.

Jones, P., (2018) A 'smart' bottom-up whole-systems approach to a zero-carbon built environment, Building Research and Information, 48(5), pp. 566-577.

Jordan, A., Bauer, M.W., and Green-Pederson, C., (2013) Policy Dismantling, Journal of European Public Policy, 20(5), pp. 795-805.

Jordana, J., (2014) Multiple crises and policy dismantling in Spain: Political strategies and distributive implications, Political Studies Review, 12(2), pp. 224-238.

Juniper, T., (2015) Tory attacks on green policies signal dark times ahead for the environment, The Guardian, http://www.theguardian.com/environment/2015/jul/24/green-policies-conservative-toryattacks-environment (accessed 24 June 2018).

Kemp, R., Schot, J., and Hoogma, R., (1998) Regime shifts to sustainability through processes of niche formation: The approach of strategic niche management, Technology Analysis and Strategic Management, 10(2), 175-196.

Kenis, A., Bono, F., and Mathijs, E., (2016) Unravelling the (post)political in Transition Management: interrogating pathways towards sustainable change, Journal of Environmental Policy and Planning, 18(5), pp. 568-584.

Kern, F., Rogge, K., (2018) Harnessing theories of the policy process for analysing the politics of sustainability transitions: a critical survey. Environmental Innovation and Societal Transitions, 27, pp. 102-117. 
Kingdon, J.W., (1984) Agendas, Alternatives and Public Policies, Little, Brown.

Koehler, J., et al., (2019) An agenda for sustainability transitions research: State of the art and future directions, Environmental Innovation and Sustainable Transitions, 31, pp. 1-32.

Levy, D.L., and Newell, P., (2002) Business strategy and international environmental governance: Toward a neo-Gramscian synthesis. Global Environmental Politics, 2(4): 84-101.

Loorbach, D., (2010) Transition management for sustainable development: A prescriptive, complexity-based governance framework, Governance, 23(1), pp. 161-183.

Lovell, H., (2007) The governance of innovation in socio-technical systems: the difficulties of strategic niche management in practice, Science and Public Policy, 34(1), pp. 35-44.

Lovell, H., (2004) Framing sustainable housing as a solution to climate change, Journal of Environmental Policy and Planning, 6(1), pp. 35-55.

Mace, M., (2018) Theresa May unveils plan to halve building energy use by 2030, https://www.edie.net/news/11/Theresa-May-unveils-plan-to-halve-building-energy-use-by-2030/ (accessed 22 May 2018).

Mark, L., (2016) Zero carbon homes policy scrapped - again, www.architectsjournal.co.uk/news/zero-carbon-homes-policy-scrapped-again/10006475.article (accessed 13 November 2018).

Matthew, E., (2017) The Tories must seize this chance to make UK homes energy efficient, The Guardian, 6 October 2017 (https://www.theguardian.com/environment/2017/oct/06/the-toriesmust-seize-this-chance-to-make-uk-homes-energy-efficient, accessed 16 March 2018).

McCleod, R.S., Hopfe, C.J., and Rezgui, Y., (2012) An investigation into recent proposals for a revised definition of zero carbon homes in the UK, Energy Policy, 46, pp. 25-35.

McNeil, A., (2016) We are mortgaging the future by scrapping zero carbon home rules, The Guardian http://www.theguardian.com/environment/2016/may/11/we-are-mortgaging-the-future-byscrapping-zero-carbon-home-rules?CMP=twt_a-environment_b-gdneco (accessed 11 May 2016)

Meadowcroft, J., (2016) Let's get this transition moving!. Canadian Public Policy, 42, pp. S10-S17.

Mlecnik, E., (2012) Defining nearly zero-energy housing in Belgium and The Netherlands. Energy Efficiency, 3, pp. 411-431.

Mueller, L., and Berker, T., (2013) Passive house at the crossroads: the past and the present of a voluntary standard that managed to bridge the energy efficiency gap, Energy Policy, 60, pp. 586-93.

Newell, P., and Paterson, M., (1998) Climate for business: Global warming, the state, and capital. Review of International Political Economy, 5(4), pp. 679-704. 
Oldfield, P., (2015) UK scraps zero carbon homes plan, The Guardian, https://www.theguardian.com/environment/2015/jul/10/uk-scraps-zero-carbon-home-target (accessed 16 March 2018).

O'Neill, K.J., and Gibbs, D.C., (2016) Rethinking Ecopreneurship: Narratives and Fluidity Amongst Green Entrepreneurs, Environment and Planning A, 48(9), pp. 1727-1749.

Osborne, H., (2007) First Zero Carbon Home Unveiled, The Guardian http://www.theguardian.com/money/2007/jun/11/property.environment (accessed June 2016).

Osmani, M., and O'Reilly, A., (2009) Feasibility of zero carbon homes in England by 2016: A house builder's perspective, Building and Environment, 44, pp. 1917-1924.

Panagiotidou, M., and Fuller, R.J., (2013) Progress in ZEBs-A review of definitions, policies and construction activity, Energy Policy, 62, 196-206.

Partzsch, L., (2017) 'Power with' and 'power to' in environmental politics and the transition to sustainability, Environmental Politics, 26(2), pp. 193-211.

Pearson, A., (2014) Government exempts 'small' sites from zero carbon homes target, Available at http://www.building4change.com/article.jsp?id1/42395 Accessed 15.07.14.

Pickerill, J., (2017) Critically interrogating eco-homes, International Journal of Urban and Regional Research, 41(2), pp. 353-365.

Pierson, P., (2004) Politics in Time, Princeton: Princeton University Press.

Pierson, P., (1994) Dismantling the Welfare State, Cambridge University Press, Cambridge.

Raven, R., Kern, F., Verhees, B., and Smith, A., (2016) Niche construction and empowerment through socio-political work. A meta-analysis of six low-carbon technology cases, Environmental Innovation and Societal Transitions, 18, pp. 164-180

Raven, R.P.J.M., Verbong, G.P.J., Schilpzand, W.F., and Witkamp, M.J., (2011) Translation mechanisms in socio-technical niches: A case study of Dutch river management, Technology Analysis and Strategic Management, 23(10), 1063-1078.

Raven, R.P.J.M., Bosch, S., van den, Weterings, R., (2010) Transitions and strategic niche management: Towards a competence kit for practitioners. International Journal of Technology Management, 51(1), pp. 55-74.

RIBA. (2015a) 2016 PART L revision sunk by zero carbon U-turn [Online]. Available at: http://www.architecture.com/RIBA/Contactus/NewsAndPress/Membernews/PracticeNews/2015/Jul y2015/16July2015/2016PartLrevisionsunkbyzerocarbonU-turn.aspx [Accessed: 14 May 2018] 
RIBA. (2015b) Chancellor urged to reconsider zero carbon decision [Online]. Available at: http://www.architecture.com/RIBA/Contactus/NewsAndPress/Membernews/PracticeNews/2015/Jul y2015/23July2015/Chancellorurgedtoreconsiderzerocarbondecision.aspx [Accessed: 14 May 2018]

Rip, A., and Kemp, R., (1998) Technological change in S Rayner and E Malone (eds.) Human Choices and Climate Change, Volume 2, Columbus, $\mathrm{OH}$ : Batelle, 327-399.

Roberts, C., and Geel, F.W., (2018) Conditions for politically accelerated transitions: Historical institutionalism, T the multi-level perspective, and two historical case studies in transport and agriculture, Technological Forecasting and Social Change, 140, pp. 221-240.

Roberts, C., Geels, F.W., Lockwood, M., Newell, P., Schmitz, H., Turnheim, B., and Jordan, A., (2018) The politics of accelerating low-carbon transitions: Towards a new research agenda, Energy Research and Social Science, 44, pp. 304-311.

Schot, J., and Geels, F.W., (2008) Strategic niche management and sustainable innovation journeys: theory, findings, research agenda, and policy. Technology Analysis and Strategic Management, 20(5), pp. 537-554.

Sheldrick, A., Evans, J., and Schliwa, G., (2017) Policy learning and sustainable urban transitions: Mobilising Berlin's cycling renaissance, Urban Studies, 54(12), pp. 2739-2762.

Shove, E., Walker, G., (2007) CAUTION! Transitions ahead: politics, practice, and sustainable transition management, Environment and Planning A, 39 (4), pp. 763-770.

Shove, E., (2010) Beyond the ABC: Climate change policy and theories of social change, Environment and Planning $A, 42(6), 1273-1285$.

Smith, A., (2003) Transforming technological regimes for sustainable development: a role for alternative technology niches? Science and Public Policy, 30(2), 127-135.

Smith, A., and Raven, R., (2012) What is protective space? Reconsidering niches in transitions to sustainability, Research Policy, 41, 1025-1036.

Smith, A., Voß, J.P., and Grin, J., (2010) Innovation studies and sustainability transitions: The allure of the multi-level perspective and its challenges, Research Policy, 39, 435-448.

Steinebach, Y., and Knill, C., (2017) Still an entrepreneur? The changing role of the European Commission in EU environmental policy-making, Journal of European Public Policy, 24(3), pp. 429446.

Sterman, J.D., (1994) Learning in and about complex systems. Systems Dynamics Review, 10, pp. 291-330. 
Truffer, B., (2008) Society, technology, and region: Contributions from the social study of technology to economic geography, Environment and Planning A, 40, 966-985.

TSO (2003) Energy White Paper: Our Energy Future - creating a low carbon economy, The Stationery Office, Norwich.

UKGBC (2008) The Definition of Zero Carbon: Zero Carbon Task Group Report, available at: https://www.ukgbc.org/sites/default/files/Definition\%2520of\%2520Zero\%2520Carbon\%2520Report. $\underline{\mathrm{pdf}}$

Walker, G., Karvonen, A., Guy, S., (2016) Reflections on a policy denouement: the politics of mainstreaming zero-carbon housing, Transactions of the Institute of British Geographers, 41, pp. 104106.

Walker, G., Karvonen, A., Guy, S., (2015) Zero carbon homes and zero carbon living: sociomaterial interdependencies in carbon governance, Transactions of the Institute of British Geographers, 40(4), pp. 494-506.

Vaughan, A., (2017) No subsidies for green power projects before 2025, says UK Treasury, The Guardian https://www.theguardian.com/environment/2017/nov/22/no-subsidies-for-green-powerprojects-before-2025-says-uk-treasury (accessed 8 August 2018)

WWF (2011) WWF-UK Resigns from Zero Carbon Taskforce https://www.wwf.org.uk/updates/wwfuk-resigns-zero-carbon-taskforce (accessed 24 June 2018).

\footnotetext{
'The Code built on an earlier government scheme, Ecohomes, as a programme of incremental change (Lovell, 2007) as opposed to 'paradigm shift'.

ii The 'Zero Carbon Hub' was a public-private partnership created in 2008 to support the delivery of the ZCH 2016 target (Greenwood 2012).

iii However, we recognize the growing debate on degrowth which argues for a downshifting of economic growth in countries like the UK as current patterns of consumption are placing a strain on ecological systems.

iv The Infrastructure Act received Royal Assent on 12 February 2015, having passed through both Houses in 2014 (DfT, 2015).

` This role was abolished in July 2016. The Department of Energy and Climate Change was 'absorbed' into the Department of Business, Energy and Industrial Strategy - meaning the UK now has no climate change specific department or Minister.

${ }^{v i}$ Secretary of State for Business, Energy and Industrial Strategy

vii https://publications.parliament.uk/pa/cm200708/cmselect/cmenvaud/566/56607.htm (following a consultation on the future of the Code for Sustainable Homes in 2008, the findings were that many thought key features should become compulsory)

viii E.g. Leeds City Council, Canterbury City Council, amongst others.

ix While 'Passivhaus' (Passive House) is more established and increasingly recognized as a low energy mode of construction, it is not without its critics - see https://www.treehugger.com/sustainable-product-design/martinholladay-rattles-cages-with-critique-of-passivhaus.html for an example.

${ }^{x}$ Association of Environmentally Conscious Building (https://www.aecb.net)
} 